\title{
Igf2 imprinting does not require its own DNA methylation or H 19 RNA
}

\author{
Beverly K. Jones, John M. Levorse, and Shirley M. Tilghman' \\ Howard Hughes Medical Institute and Department of Molecular Biology, Princeton University, \\ Princeton, N ew Jersey 08544 USA
}

\begin{abstract}
Three models have been proposed to explain the imprinting of the mouse Igf 2 gene on the matemal chromosome. We ruled out the importance of DNA methylation at Igf2 by showing that silencing of Igf2 accompanying the loss of DNA methylation could be overcome by a mutation at the neighboring $\mathrm{H} 19$ gene that activates Igf2. By replacing the $\mathrm{H} 19$ structural gene with a protein-coding gene, we have ruled out a role for H 19 RNA in the imprinting of Igf2. This replacement resulted in sporadic activation of the H 19 promoter on the patemal chromosome without affecting the level of expression of Igf2, a finding that is inconsistent with strict promoter competition between the genes. We conclude that a transcriptional model involving access to a common set of enhancers shared between Igf2 and H 19 is the most likely explanation for Igf2 imprinting
\end{abstract}

[Key Words: Genomic imprinting; H19; Igf2; DN A methylation; promoter competition; chromatin]

Received M arch 23, 1998; revised version accepted M ay 15, 1998.

The mammalian genome harbors a small number of genes whose expression is affected by the parental origin of the chromosome, a process known as genomic imprinting (Barlow 1995; Bartolomei and Tilghman 1997). The number of imprinted genes that have been identified now numbers $>20$, and comparisons among these genes have begun to reveal some common features. Foremost among these is allele-specific DNA methylation, which has been implicated in the mechanism by which a cell discriminates between the two parental alleles of an imprinted gene and determines which will be transcribed (Li et al. 1993). Furthermore, imprinted genes are frequently linked within clusters that contain both maternally and paternally expressed genes (Zemel et al. 1992; Mutirangura et al. 1993; Rougeulle et al. 1997; Vu and Hoffmann 1997; Wutz et al. 1997). Finally, an unusual feature of these clusters is that they contain at least one imprinted gene that encodes an untranslated RN A (Brannan et al. 1990; Kay et al. 1993; Wevrick et al. 1994; Wutz et al. 1997).

All of these properties are evident within an $\sim 800-k b$ cluster of genes that resides on the distal end of mouse chromosome 7 (Caspary et al. 1998). This cluster contains the paternally expressed insulin-like growth factor 2 (I gf2) and insulin-2 (Ins2) genes, which are flanked on the telomeric side by the maternally expressed $p 57^{\mathrm{Kip} 2}$, Mash2, and $K_{v}$ lqt1 genes and on the centromeric si de by the maternally expressed $\mathrm{H} 19$ gene. Of these genes, the one whose imprinting mechanism is best understood is $\mathrm{H} 19$, which encodes the first of the untranslated RNAs

${ }^{1}$ Corresponding author.

E-MAIL stilghman@molbio.princeton.edu; FAX (609) 258-3345. to be shown to be imprinted (Brannan et al. 1990; Bartolomei et al. 1991). The silence of H19 on the paternal chromosome is thought to be the result of DNA methylation within the gene and its 5 ' flank that is established during spermatogenesis and maintained throughout embryogenesis (Bartol omei et al. 1993; Brandei s et al. 1993; Ferguson-Smith et al. 1993; Li et al. 1993).

The absence of any DNA methylation on the silent I gf2 gene forced us to consider alternative models to explain its imprinting. In fact, it is the expressed paternal allele of I gf 2 that is specifically methylated in two locations: within the gene itself and in its $5^{\prime}$ flank (Sasaki et al. 1992; Feil et al. 1994). Furthermore, this correlation between methylation and expression of Igf2 extends to the choroid plexus, a tissue that expresses both allel es of I gf2 and exhibits biallelic methylation (DeChiara et al. 1991; Feil et al. 1994; Svensson et al. 1995), and to mutations at $\mathrm{H} 19$ that activate Igf2 (Forne et al. 1997). These results, taken together with the loss of Igf2 expression in embryos deficient in DN A methyltransferase (Dnmt), led to the proposal that methylation was acting as a positive signal for transcription, possibly by inhibiting the binding of a repressor (Walter et al. 1996).

An alternative to this hypothesis was based on the very similar patterns of expression of Igf 2 and H 19 during development. Bartolomei and Tilghman (1992) proposed that their imprinting is linked through a competition for a common set of transcriptional enhancers. In this scenario, the silence of the maternal I gf2 gene is a consequence of its failure to compete successfully with the unmethylated $\mathrm{H} 19$ gene in cis. This model gained considerable support when it was demonstrated that both genes require for their expression two endoderm- 
specific enhancers that lie $3^{\prime}$ of the $\mathrm{H} 19$ gene (Leighton et al. 1995b). Furthermore, the insertion of an extra set of enhancers between the two genes results in the activation of the unmethylated maternal I gf2 gene (Webber et al. 1998). Finally, two targeted mutations that del ete the competitor $\mathrm{H} 19$ gene and either $10 \mathrm{~kb}\left(\mathrm{H}_{19^{\Delta 13}}\right)$ or $40 \mathrm{bp}$ $\left(\mathrm{H}^{19^{\Delta 3}}\right)$ of its $5^{\prime}$ flank also result in complete or partial activation, respectively, of the maternal I gf 2 gene $90 \mathrm{~kb}$ away (Leighton et al. 1995a; Ripoche et al. 1997).

In this report we perform an epistasis test to assess the relative importance of DN A methylation, versus the absence of the $\mathrm{H} 19$ regi on, to Igf 2 expression. We conclude that the I gf 2 gene does not require DNA methylation for its expression in the embryo. Furthermore, we generate a targeted replacement of the $\mathrm{H} 19$ structural gene to definitively show that the RNA itself plays no role in the imprinting of Igf2.

\section{Results}

Igf2 is expressed in the absence of DNA methylation in H19 mutant animals

To assess the relative importance of methylation in I gf2 imprinting, we performed an epistasis test to ask whether the silencing of Igf2 by loss of DNA methylation in $\mathrm{Dnmt}^{-1-}$ embryos could be overcome by the $\mathrm{H} 19^{\Delta 13}$ mutation that activates maternal expression of Igf2. We utilized mice bearing the null $\mathrm{Dnmt}^{\mathrm{S}}$ allele; homozygous mutant embryos do not survive past e10, and exhibit a marked reduction in both genome-wide and I gf2-specific methylation ( $\mathrm{Li}$ et al. 1992, 1993; Tucker et al. 1996). Dnmt ${ }^{-1-}$ embryos that had al so inherited the $\mathrm{H}^{19^{\Delta 13}}$ mutation on either the maternal or paternal chromosome were harvested at e9.5. DNA was prepared from yolk sacs for genotyping, and the level s of Igf2 RNA were determined by RNase protection in pooled embryos of the same genotype. As the results in Figure 1 illustrate, Igf2 expression is unaffected by the loss of DNA methylation when the $\mathrm{H}^{-19^{\Delta 13}}$ mutation is present. The levels of Igf2 expression in $\mathrm{Dnmt}^{-1}$; $\mathrm{H} 19^{\Delta 13} /+$ embryos were similar to those obtained in

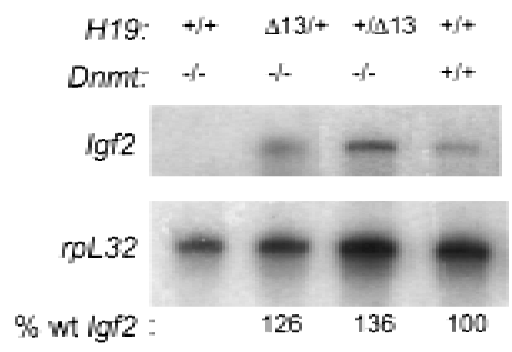

Figure 1. Expression of I gf $2 \mathrm{RN} A$ in Dnmt ${ }^{-1-} ; \mathrm{H} 19^{\Delta 13 /+}$ double mutant embryos. Embryos were generated by crossing Dnmt ${ }^{+1}$ heterozygotes to $\mathrm{Dnmt}^{+/} ; \mathrm{H}_{1} 9^{\Delta 13 /+}$ double heterozygotes. Embryos were pooled according to genotype and the levels of Igf2 and rpL32 mRN As were determined by RN ase protection. The level of I gf 2 RNA is expressed as a percent of that in wild-type embryos, after normalization to rpL32 RN A by Phosphorlmager densitometry.
$\mathrm{Dnmt}^{+/+}$|ittermates, on the basis of comparisons with rpL32 RNA, which served as an internal control. The levels were independent of the parental origin of the $\mathrm{H} 19^{\Delta 13}$ mutation, as would be predicted if the loss of methylation had erased all differences between the parental chromosomes. From this observation, we conclude that the expression of Igf2 at this stage in development does not require DNA methylation, but does require the methylation or deletion of the $\mathrm{H} 19$ gene region.

\section{Igf2 imprinting does not require H19 RNA in cis}

Although the original enhancer competition model predicted a strictly transcriptional role for the $\mathrm{H} 19$ gene in I gf2 imprinting, a function for the RN A product of the gene has been suggested, as both the $\mathrm{H} 19^{\Delta 13}$ and $\mathrm{H}^{19^{\Delta 3}}$ mutations that disrupted I gf2 imprinting removed both the promoter and the structural $\mathrm{H} 19$ gene (Leighton et al . 1995a; Ripoche et al. 1997). M oreover, the presence of untranslated RNAs in multiple imprinted regions, together with the compelling evidence that expression of an untranslated RNA encoded by the Xist gene is re qui red for X chromosome inactivation (Penny et al. 1996; Marahrens et al. 1997), raised expectations that there might be some function for these RNAs in imprinting. Functional evidence for the importance of sequences within the $\mathrm{H} 19$ structural gene came from the experiments of Pfeifer et al . (1996) who observed that when the H19 structural gene was replaced with the luciferase gene within the context of a 14-kb transgene, imprinting of the transgene was lost.

To examine the role of H19 RNA in the silencing of I gf2, a targeting strategy was devised to delete all but the first three nucleotides of the $\mathrm{H} 19$ transcript and replace them with a gene coding for the protein luciferase (luc) (Fig. 2). The neomycin resistance $\left(\right.$ neo $\left.^{R}\right)$ selectable marker was flanked by loxP sites to facilitate removal by Cre-mediated homologous recombination, which would leave the targeted locus modified only within the coding regi on of the $\mathrm{H} 19$ gene (Sauer and Henderson 1989). Correctly targeted events and accurate excision of ne ${ }^{R}$ were verified with probes that lie outside of the targeting vector (Fig. 2B). RNase protection analysis confirmed the absence of maternal H19 RNA (data not shown).

The expression of the luc gene in neonatal liver was examined by an RN ase protection assay in progeny of $\mathrm{H} / \mathrm{H} 19^{\text {luc }}$ mothers (Fig. 3A). Regardless of whether the mutation was on the grandmaternal or grandpaternal chromosome, the gene was expressed at equival ent levels, suggesting that resetting from a male to a female epigenetic state was occurring. Similar results were obtained in skeletal muscle (data not shown). To ask whether the maternally inherited $\mathrm{H} 19^{\text {luc }}$ locus was unmethylated, the $5^{\prime}$ flank and the luc gene were examined by digestion of genomic DNA from neonatal liver with methylation-sensitive restriction enzymes (Fig. 3B). A region encompassing from -2 to $-4 \mathrm{~kb}$ within the $5^{\prime}$ flank of the gene, which is thought to contain the primary paternal gametic mark but is al ways unmethylated 
Jones et al.

A
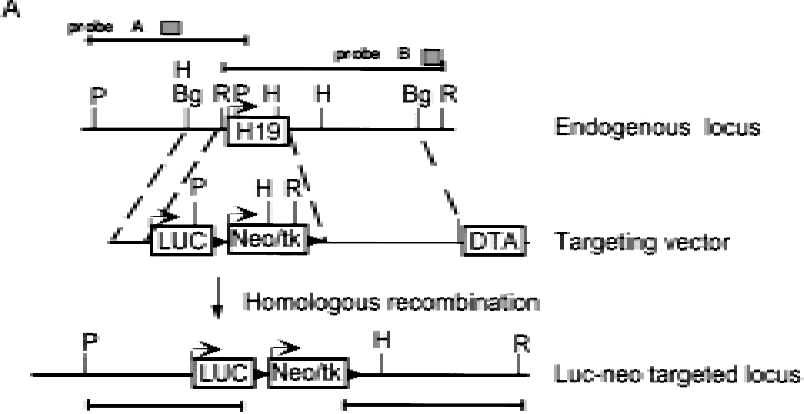

B
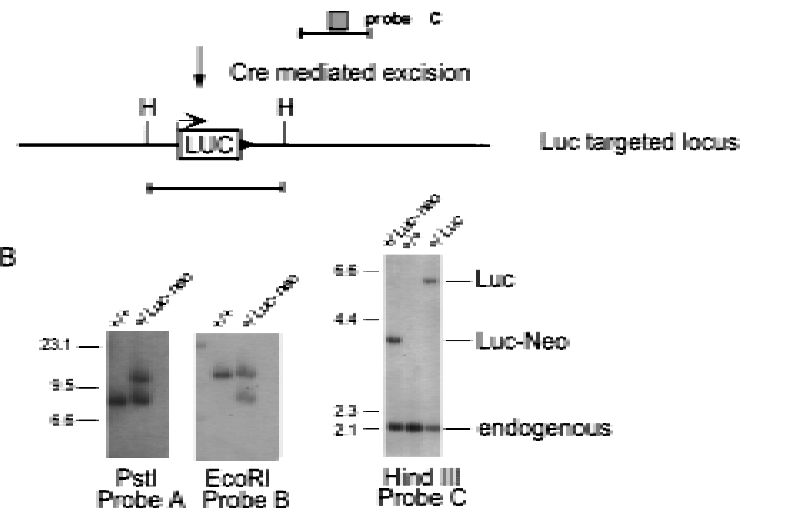

Figure 2. Strategy for replacing $H 19$ RNA with luciferase RN A. (A) Structure of the endogenous $\mathrm{H} 19$ locus, al ong with the positions and sizes of restriction fragements and radiolabeled probes (shaded boxes) used in B, are illustrated at the top. The targeting vector contains the luciferase coding region (LUC) inserted at +3 bp of the $\mathrm{H} 19$ structural gene, followed by the neo ${ }^{R}$ gene linked to the tk gene by an internal ribosomal entry site $\left(n e \mathrm{o}^{\mathrm{R}} / \mathrm{tk}\right)$ driven by the phosphoglycerokinase promoter. The neo/tk gene is flanked by loxP sites from bacteriophage P1 $(\triangleright)$. The regions of homology between the targeting vector and the endogenous locus are indicated by broken lines. The vector also includes the diphtheria toxin A (DTA) chain gene for negative selection (M cCarrick et al. 1993). The structure of the correctly targeted locus, before and after excision of neo/tk with Cre recombinase, are illustrated, along with the restriction fragments used to diagnose them. The position of probe $C$ is indicated by the shaded box. (B) DNAs prepared from E14.1 wildtype cells $(t /+)$ and a correctly targeted line before ( + Luc-N eo) and after ( $+/$ Luc) excision of $\mathrm{Neo} / \mathrm{tk}$ were analyzed by digestion with restriction enzymes and hybridized to probes $A-C$, as indicated. The size marker was $\lambda$ DN A digested with HindlII. (P) Pstl; (Bg) Bglll; (R) EcoRI; (H) HindlII.

on the maternal chromosome (Tremblay et al. 1995, 1997), is equally unmethylated in maternal H $19^{\text {luc }}$ mice. The lack of methylation is also evident within the promoter and the luc gene itself (data not shown). These results are consistent with the findings of Ripoche et al (1997), who showed that a neo ${ }^{R}$ gene inserted in place of the $\mathrm{H} 19$ promoter and structural gene was appropriately unmethylated and expressed on the maternal chromosome.

Although there is no requirement for maternal $\mathrm{H} 19$ RNA in the embryo, the RN A could be required in trans for setting the maternal imprint in primordial germ cells or in early germ-cell development, in which the gene has been shown to be expressed from both chromosomes (Szabo and M ann 1995). To test this, we examined transmission of a paternal ly inherited $\mathrm{H} 19^{\text {luc }}$ allele from both $\mathrm{H} 19^{\text {luc }}$ homozygous and $\mathrm{H} 19^{\Delta 13} / \mathrm{H} 19^{\text {luc }}$ females. The females were crossed to wild-type males and $H / H 19^{\Delta 13}$ males so that the expression and methylation of the

A

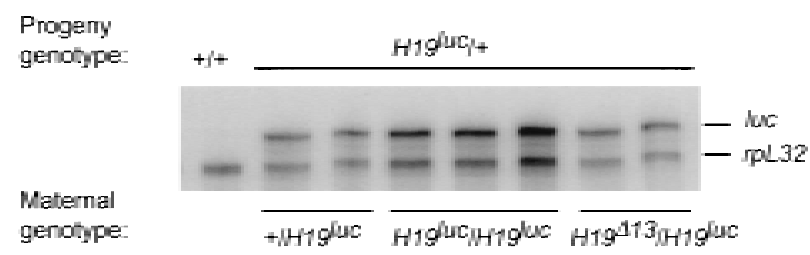

B
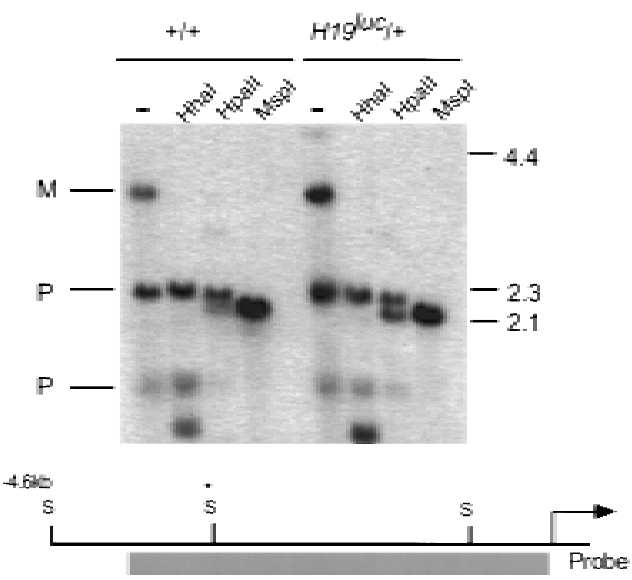

C

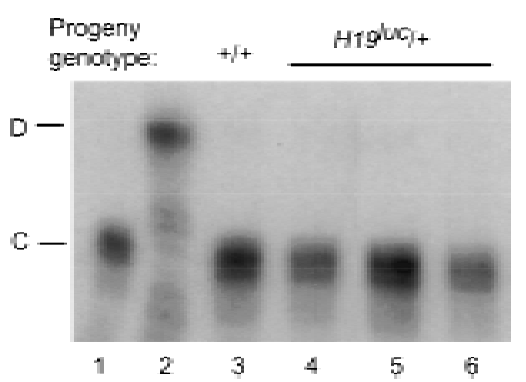

Figure 3. Maternal inheritance of H19luc. (A) Expression of $\mathrm{H} 19^{\text {luc }}$ and rpL32 were measured by RN ase protection in day 4 and 5 neonatal livers of progeny of $+/ \mathrm{H} 19^{\text {luc }}, \mathrm{H} 19^{\text {luc }} / \mathrm{H} 19^{\text {luc }}$, and $\mathrm{H} 19^{\Delta 13} / \mathrm{H} 19^{\text {luc }}$ mothers and M. castaneus ( + ) fathers. (B) Genomic DNA from wild type $(H+)$ and progeny of $\mathrm{H} 19^{\text {luc }} /+$ females and $M$. castaneus males was digested with Sacl al one $(-)$ or Sacl together with $\mathrm{H}$ pall, Hhal, or Mspl, as indicated. The DNA was detected with a 4-kb EcoRI hybridization probe (shaded rectangle) derived from the $5^{\prime}$ end of the $\mathrm{H} 19$ gene. The positions of the Sacl (S) sites, including the polymorphic site in M. castaneus $\left(S^{*}\right)$ are indicated, al ong with the start of $\mathrm{H} 19$ transcription (arrow). (M) M aternal al lele; (P) paternal allele. The size markers are indicated at right. (C) Igf2 RNA was assayed by an allelespecific RN ase protection assay in a subset of the animals described in A as well as in M. castaneus neonatal liver (C, lane 1 ) and C57BL/6J liver (D, lane 2). The maternal genotypes are $H$ $\mathrm{H} 19^{\text {luc }}$ (lane 4$), \mathrm{H} 19^{\text {luc }} / \mathrm{H} 19^{\text {luc }}$ (lane 5$)$, and $\mathrm{H} 19^{\Delta 13} / \mathrm{H} 19^{\text {luc }}$ (lane 6). 
$\mathrm{H} 19^{\text {luc }}$ gene could be assessed in either the presence or absence of the paternally provided $\mathrm{H} 19$ gene. No differences in the expression of H19luc RN A were observed in any of these genetic combinations, providing strong evidence that there is no requirement for H19 RNA in the maternal germline for resetting or maintaining the unmethylated, transcriptionally active status of the $\mathrm{H} 19^{\text {luc }}$ allele (Fig. 3A and data not shown).

Having verified that replacement of $\mathrm{H} 19$ with luc resulted in normal maternal expression from the $\mathrm{H} 19$ promoter, we next examined the impact of this mutation on Igf2 imprinting. Heterozygous, homozygous, and compound heterozygous female mice bearing the $\mathrm{H} 19^{\text {luc }}$ allele $\left(\mathrm{H} 19^{\mathrm{luc}} /+, \mathrm{H} 19^{\mathrm{luc}} / \mathrm{H} 19^{\mathrm{luc}}\right.$, and $\left.\mathrm{H} 19^{\mathrm{luc}} / \mathrm{H} 19^{\Delta 13}\right)$ were crossed to Mus castaneus males and I gf2 expression was examined in livers and skeletal muscle from neonatal progeny by allele-specific RN ase protection (Fig. 3C; data not shown). N o activation of the maternal I gf2 gene was observed under any circumstance, establishing that imprinting of the I gf2 gene does not require the presence of the H19 RNA in cis. Thus, unlike the previous two mutations at $\mathrm{H} 19$, both of which removed the promoter and structural gene, the loss of the structural gene al one has no consequence for Igf2 imprinting.

Sporadic methylation and silencing of $\mathrm{H} 19^{\text {luc }}$ on the paternal chromosome

When the H19luc mutation was inherited from fathers, the level of expression of luc RNA in the progeny was surprisingly variable, suggesting that there had been sporadic relaxation of the imprint (Fig. 4). The levels varied from $5 \%$ to $55 \%$ of that measured in age-matched progeny inheriting $\mathrm{H} 19^{\text {luc }}$ maternally, on the basis of comparisons with the levels of rpL32 RN A for normalization. The variability could not be ascribed to the presence or absence of wild-type $\mathrm{H} 19$ during spermatogenesis in the father, as progeny of both $\mathrm{H} 19^{\text {luc }}$ homozygotes and $\mathrm{H} 19^{\mathrm{luc}} / \mathrm{H} 19^{\Delta 13}$ males displayed the same degree of variability in luc imprinting as those from $\mathrm{H} 19^{\text {luc }}$ heterozygotes. Furthermore, the variability did not depend on the presence of H19 RNA during embryogenesis, as it occurred in both $\mathrm{H} / \mathrm{H} 19^{\text {luc }}$ and $\mathrm{H}_{19^{\Delta 13}} / \mathrm{H} 19^{\text {luc }}$ progeny (Fig 4).

To examine the basis for the variability, the levels of luc methylation in progeny showing relaxation of the imprint after paternal inheritance were examined. To simplify the analysis, we used tissues from $\mathrm{H}_{19}{ }^{\Delta 13}$ / $\mathrm{H} 19^{\text {luc }}$ animals in which the $\mathrm{H} 19$ gene and its 5' flank were deleted on the maternal chromosome. In progeny exhibiting the lowest levels of luc expression, the methylation pattern was indistingui shable from that observed on a wild-type paternal H19 gene throughout the 5' flank; that is, both the 4-kb Sacl fragment encompassing the gametic imprint as well as the smaller promoter fragment resisted digestion with Hhal. Moreover, this methylation extended into the luc gene itself, reminiscent of the methylation of the H19 structural gene (data not shown). In contrast, in animals in which the expression of luc was detected, there was an inverse correl ation between the expression level and the degree of methylation of the promoter, but not the 5' gametic imprint region, which remained fully methylated (Fig. 5). Thus, the replacement of the $\mathrm{H} 19$ structural gene with the luc gene results in some degree of undermethylation of the promoter and sporadic expression of luc. This result suggests that sequences within the $\mathrm{H} 19$ structural gene contribute to the maintenance of its silent state on the paternal chromosome. CpG density alone, however, cannot account for this, as the luc gene, which is almost identical in length to $\mathrm{H} 19$, has almost twice the number of CpG dinucleotides. On the other hand, the luc gene's overall $\mathrm{G}+\mathrm{C}$ content is $43 \%$, which is closer to the genome average than $\mathrm{H} 19$, which is $56 \%$.

The sporadic expression of luc on the paternal chromosome provides an explanation for the failure of $\mathrm{H} 19$ luc fusion transgenes to be imprinted (Pfei fer et al. 1996). One difference between the luc transgene and the germline replacement is the maintenance of DNA methylation in the $5^{\prime}$ flank in the latter. It may be that the 14-kb transgenes contained only a subset of the epigenetic information required for maintenance of DNA methylation, a conclusion that is consistent with the recent observation that single copy $130-\mathrm{kb}$ Y AC transgenes of the locus are correctly imprinted (Ainscough et al . 1997).

\section{H19 luc expression has no effect on Igf2 expression}

It was of considerable interest to ask whether transcription of luc on the paternal chromosome affected Igf2

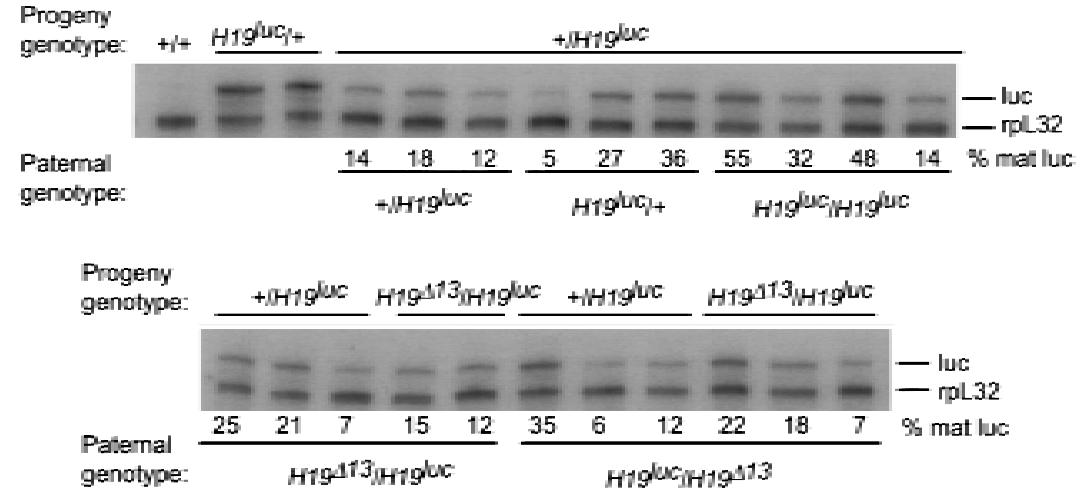

Figure 4. Expression of luc RNA upon paternal inheritance. Males of the genotype indicated (paternal genotype) were crossed to wild-type $(H+)$ females or $+/ H 19^{\Delta 13}$ females and the levels of luc RN A and rpL32 RN A was determined by $\mathrm{RN}$ ase protection assay in neonatal livers of the progeny. The levels of luc RNA, as determined by Phosphorlmager densitometry and normalization to rpL32 RNA levels, are expressed as a percent of the level upon maternal inheritance (H19luc/ +$)$. 


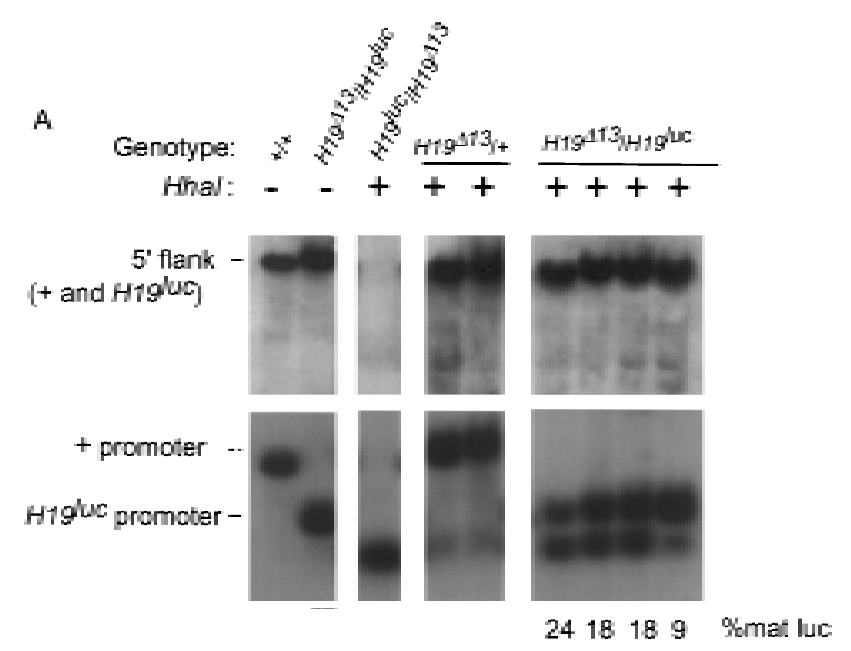

B

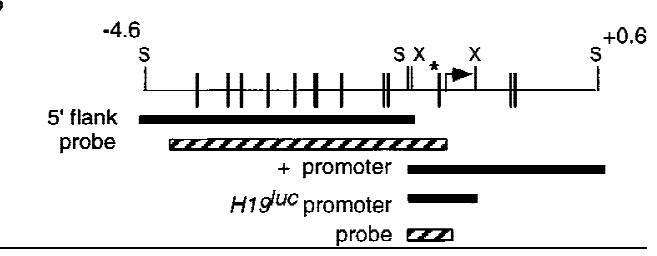

Figure 5. Effect of paternal $\mathrm{H} 19^{\mathrm{luc}}$ inheritance on DNA methylation. (A) Genomic DNA from livers of wild-type $(H+),+$ $\mathrm{H} 19^{\text {luc }}$ heterozygotes, and $\mathrm{H} 19^{\Delta 13} / \mathrm{H} 19^{\text {luc }}$ homozygotes were digested with Sacl and Xbal al one (-, first two lanes) or Sacl, Xbal, and $\mathrm{H}$ hal $(+)$, separated on $1 \%$ agarose gels, and hybridized to a 4-kb EcoRI fragment that detects the 3.8-kb Sacl fragment in the $5^{\prime}$ flank of the +and $\mathrm{H} 19^{\text {luc }}$ alleles (top) or a 600-bp Xbal-EcoRI fragment from the $5^{\prime}$ end of the $\mathrm{H} 19$ gene that detects a $1.2-\mathrm{kb}$ Sacl fragment encompassing the + promoter and a 0.7-kb Xbal fragment encompassing the $\mathrm{H} 19^{\text {luc }}$ promoter (bottom). The level of expression of paternal luc RNA in the four compound heterozygotes is indicated as a percent of maternal luc RNA expression. (B) A map of the $\mathrm{H} 195^{\prime}$ region, with the start of transcription indicated by the arrow, is drawn below, al ong with the positions of the Sacl and $\mathrm{Xbal}$ fragments assayed (solid rectangles). (S) Sacl; (X) Xbal. (|) Hhal; (*) Hhal site assayed in the bottom of $A$. The probes used in $A$ are indicated by hatched boxes.

expression. If a strict competition for transcription governs its expression, we would anticipate a decrease, anal ogous to the effect of mutations in the $\beta$-gl obin gene promoter on $\gamma$-globin gene expression in chickens, in which promoter competition has been clearly demonstrated (Choi and Engel 1988; Foley and Engel 1992). However, there was no correl ation between the levels of I gf2 RN A (normalized to rpL32 RN A levels) and the expression of paternal luc RNA (Fig. 6A). Moreover, the birth weights of the animals were unaffected by paternal luc expression (Fig. 6B). These data argue against a strict competition between the $\mathrm{H} 19$ and Igf2 promoters in maintaining imprinted I gf2 expression.

\section{Discussion}

The maintenance of Igf2 imprinting in mice that have substituted luc for the $\mathrm{H} 19$ coding region rules out a role for H19 RNA itself in imprinting. Two previous mutations at the locus, both of which removed both the H19 gene and its promoter, had resulted in the inappropriate expression of the maternal I gf2 gene (Leighton et al. 1995a; Ri poche et al. 1997). These findings, coupled with the demonstration by Marahrens et al (1997), that the Xist gene itself is required for $X$ chromosome inactivation, made the H19 RNA an attractive candidate for playing a role in imprinting. However, this is clearly not the case. Instead, the important epigenetic mark for I gf2 imprinting must lie in the vicinity of the promoter and the $5^{\prime}$ flank of the $\mathrm{H} 19$ gene.

The fact that the H19luc mice display no phenotype whatsoever leaves unexplained the evolutionarily conserved primary sequence and secondary structure of the RNA (Brannan et al. 1990; Pfeifer and Tilghman 1994). It could be that the RNA has a function unrelated to imprinting that is either nonessential or redundant. Alternatively, it could be that the sole function of the gene is to be transcribed at high rates to imprint Igf2 and that the conservation of its product reflects the necessity of packaging and sequestering a very abundant RN A. If so, this would be an entirely novel function for a gene.

From the outset, the epigenetic configuration of the I gf2 and H19 genes suggested that the genes were not being regulated identically. The finding of extensive methylation of the paternally inherited $\mathrm{H} 19$ gene suggested a straightforward expl anation for its silence, gi ven the long-standing correl ation between gene silencing and DNA methylation. Furthermore, the differential hypersensitivity of the maternal and paternal $\mathrm{H} 19$ promoters to nuclease digestion reinforced the idea that the two alleles were in different chromatin conformations (Bartolomei et al. 1993; Brandeis et al. 1993; Ferguson-Smith et al. 1993). In contrast, I gf2 is methylated excl usively on the expressed paternal chromosome, and the two parental promoters are in equal ly hypersensitive states (Sasaki et al. 1992). Despite the correlation between I gf2 methylation and expression observed in vivo, our findings demonstrate that this methylation is not required for Igf2 expression, but is likely the consequence of its expression.

The initial model proposed by Bartolomei and Tilghman (1992) suggested that the transcriptional status of H19 was mediating the imprinting of I gf2. The possibility of pairing a transcription unit that is the target of epigenetic information (i.e., H 19) with an oppositely imprinted response gene (Igf2) has now been raised for another imprinted gene, I gf2r. Like I gf2, its methylated epigenetic mark occurs on the expressed maternal chromosome, within a large intron of the gene (Stoger et al. 1993). Wutz et al (1997) have now shown that this C pG island is the promoter for a paternally expressed antisense transcript that is required for I gf2r imprinting. Barlow (1997) has suggested that the mechanism underlying I $g$ 2 $2 r$ imprinting is promoter competition with the antisense RN A coding gene, like the one we have described at Igf2 and $\mathrm{H} 19$.

More recent observations suggest that imprinting control may be more complex than strict promoter compe- 
A

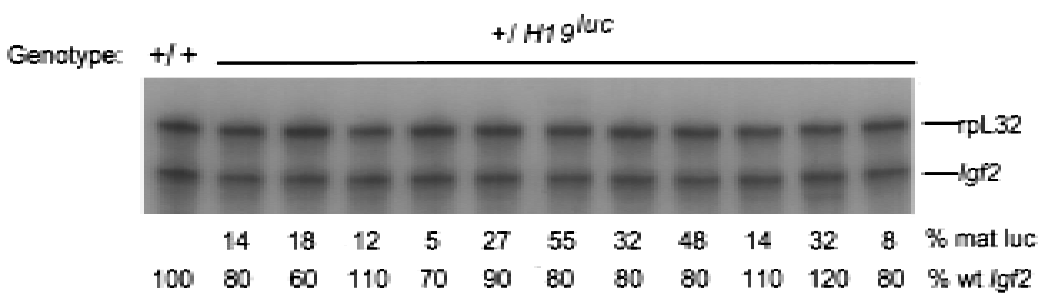

B

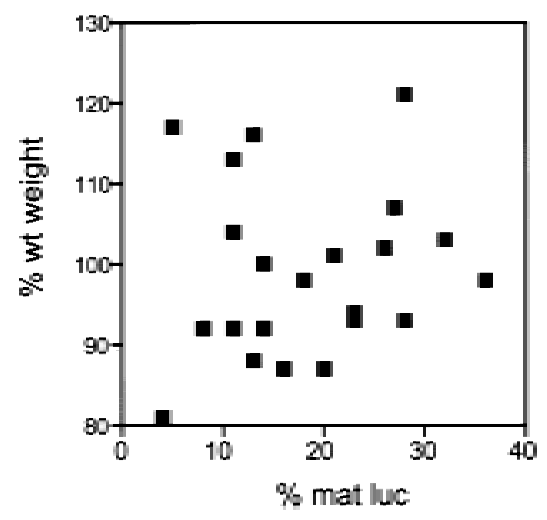

Figure 6. Effect of paternal luc expression on I gf2 expression. (A) Expression of I gf2 and rpL32 RNAs in paternal H19luc heterozygotes was determined by an RN ase protection assay (Webber et al. 1998). The level of luc RN A in each animal is indicated as a percent of maternal luc RNA, and the level of Igf2 RNA is expressed as a percent of that in wild-type embryos after normalization to rpL32 RNA by Phosphorlmager densitometry. (B) The weights of $+/ H 19^{\text {luc }}$ neonatal offspring (expressed as percent of mean $+/+$ littermate weight) were plotted against paternal luc RNA expression (expressed as percent of maternal luc RNA levels). tition. First, in an effort to understand the basis for the competition between Igf2 and $\mathrm{H} 19$, we transposed the 3' H19 enhancers to a position midway between the genes (Webber et al . 1998). To our surprise, the I gf2 gene was expressed to the exclusion of H19, essentially reversing the direction of the imprint on the maternal chromosome. This argues that the position of a gene and its enhancers relative to the epigenetic mark may play a crucial role in the nature and direction of the imprint.

Second, in this report we observed significant levels of expression of the paternal luc gene without a concomitant change in the expression of Igf2, a finding that directly contradicts strict promoter competition. It is possible that the substitution of the luc gene for $\mathrm{H} 19$ reduced the transcription rate from the $\mathrm{H} 19$ promoter, and thus, it is a poor competitor for transcription with Igf2. However, if this were the case, according to strict promoter competition, one might have expected an increase in maternal Igf2 expression. Rather, it appears that the reciprocal expression of $\mathrm{H} 19$ and Igf2 is unlike that between the adult and embryonic chicken $\beta$-globin genes, in which an increase in expression of one gene is al ways accompanied by a decrease in the other (Fol ey and Engel 1992). Our data show that the H19 promoter can be active on the paternal chromosome without decreasing Igf2 expression. On the basis of both of these studies, we propose that it is the methylation of the epigenetic mark upstream of $\mathrm{H} 19$ that is essential for I gf 2 expression, and would further suggest that the function of methylating this mark may be to inactivate a chromatin boundary that isolates Igf2 from the downstream enhancers. On the maternal chromosome, where the epigenetic boundary is unmethylated, and therefore active, Igf 2 is insulated from its transcriptional regulatory elements.

\section{Material and methods}

Mutant genotyping

Dmnt genotyping was accomplished by a PCR reaction that detected both the wild-type locus with forward Dmnt 1114 primer (5'-CCTTCAGTGTGTACTGCAGTCG-3') and reverse Dmnt 1169 primer (5'-AATGAGACCGGTGTCGACAG-3') and the targeted locus with forward Dmnt 1114 primer and reverse Pgk3 primer (5'-CTTGTTGTAGCGCCAAGTGC-3'). Genomic DN A (100 ng) was amplified for 35 cycles at $90^{\circ} \mathrm{C}$ for $30 \mathrm{sec}, 53^{\circ} \mathrm{C}$ for $30 \mathrm{sec}, 72^{\circ} \mathrm{C}$ for $30 \mathrm{sec}$ in $20 \mu \mathrm{l}$.

$\mathrm{H} 19^{\Delta 13}$ is a replacement from an EcoRI site at $-10 \mathrm{~kb}$ to a Sall site at $+3 \mathrm{~kb}$ at the $\mathrm{H} 19$ locus with the Pgkneo cassette (Leighton et al. 1995a). Genotyping was performed by use of the forward primer in the region $5^{\prime}$ of the $\mathrm{H}^{1} 9^{\Delta 13}$ del etion ( $5^{\prime}$-CAGTGT GG GAAACA GCCT-3') and Pgk3 for the reverse primer. Iuc genotyping by PCR utilized the forward primer LH195' (5'-GCCATGTACTGATTGGTTGA-3') and the reverse primer Luc3' (5'-TTGCTCTCCAGCGGTTCCAT-3'). Conditions for amplificaton were identical to those used for Dmnt genotyping.

RNA analysis

RN As were prepared from pools of from four to five embryos in the Dnmt; $119^{\Delta 13}$ crosses with the RN aqueous kit from Ambion. Ten micrograms of each RNA were hybridized to radiolabeled RNA antisense probes specific for rpL32 (Webber et al. 1998), I gf2 (Leighton et al. 1995a), and H19 (Brunkow and Tilghman 1991) by use of the Ambion RPAll kit. Protected fragments were resolved by electrophoresis on $7.5 \%$ denaturing acrylamide gels run in $1 \times$ TBE.

The luc riboprobe was generated by ligating a 540-bp XbalEcoRI fragment from pGL2 into BS KSII-, linearizing with BsrFI and transcribing with $\mathrm{T} 3$ polymerase. Ten micrograms of total neonatal liver RNA was used in each assay.

Generation of $\mathrm{H} 19^{\text {luc }}$ mutant mice

$\mathrm{H} 19$ genomic clones were isolated from a 129Sv/J bacteriophage 
genomic library (Stratagene). A BgllI-Dralll fragment of the $\mathrm{H} 19$ $5^{\prime}$ flank from $-1.8 \mathrm{~kb}$ to $+3 \mathrm{bp}$ and a Sall-Bglll 6.5-kb fragment of $\mathrm{H}_{19} 3^{\prime}$-flanking sequence were cloned into Bluescript KSII-. The luc was isolated from the pGL2 vector (Promega) as a HindlII-Sall fragment and ligated to the $5^{\prime}$ arm. The diptheria toxin A-chain cassette was ligated downstream of the $3^{\prime}$ homologous sequence. neo/tk (Wu et al. 1994) was ligated between two tandem loxP sites and inserted immediately $3^{\prime}$ of luc in the final targeting vector. E14.1 ES cells (Kuhn et al. 1991) were transfected as described (Webber et al. 1998) and sel ected for 6-7 days with $200 \mu \mathrm{g} / \mathrm{ml} \mathrm{G} 418$ (active) before picking neo ${ }^{\mathrm{R}}$ clones. Cre excision and derivation of chimeric mice and germ-line offspring were performed as described (Webber et al. 1998).

\section{Acknowledgments}

We thank Dr. Rudolph Jaenisch for providing the Dnmt mutant mice, and members of the laboratory for helpful discussions. This work was supported by a grant from the $\mathrm{N}$ ational Institute of General Medical Sciences. B.K.J. is supported by a $\mathrm{N}$ ational Research Service A ward from the $\mathrm{N}$ ational Institutes of Health and S.M.T. is an Investigator of the Howard Hughes Medical Institute.

The publication costs of this article were defrayed in part by payment of page charges. This article must therefore be hereby marked "advertisement" in accordance with 18 USC section 1734 solely to indicate this fact.

\section{References}

Ainscough, J.F.-X., T. Koide, M. Tada, S. Barton, and A. Surani. 1997. Imprinting of I gf2 and $\mathrm{H} 19$ from a $130 \mathrm{~kb}$ YAC transgene. Devel opment 124: 3621-3632.

Barlow, D.P. 1995. Gametic imprinting in mammals. Science 270: 1610-1613.

- - . 1997. Competition-A common motif for the imprinting mechanism? EMBO J. 16: 6899-6905.

Bartolomei, M.S. and S.M. Tilghman. 1992. Parental imprinting of mouse chromosome 7. Semin. Dev. Biol. 3: 107-117.

- - . 1997. Genomic imprinting in mammals. Annu. Rev. Genet. 31: 493-525.

Bartolomei, M.S., S. Zemel, and S.M. Tilghman. 1991. Parental imprinting of the mouse $\mathrm{H} 19$ gene. Nature 351: 153-155.

Bartolomei, M.S., A.L. Webber, M.E. Brunkow, and S.M. Tilghman. 1993. Epigenetic mechanisms underlying the imprinting of the mouse H19 gene. Genes \& Dev. 7: 1663-1673.

Brandeis, M., T. Kafri, M. Ariel, J.R. Chaillet, J. M cCarrey, A. Razin, and H. Cedar. 1993. The ontogeny of allele-specific methylation associated with imprinted genes in the mouse. EMBO J. 12: 3669-3677.

Brannan, C.I., E.C. Dees, R.S. Ingram, and S.M. Tilghman. 1990. The product of the $\mathrm{H} 19$ gene may function as an RNA. Mol. Cell. Biol. 10: 28-36.

Brunkow, M.E. and S.M. Tilghman. 1991. Ectopic expression of the H19 gene in mice causes prenatal lethality. Genes \& Dev. 5: 1092-1101.

Caspary, T., M.A. Cleary, C.C. Baker, X.-J. Guan, and S.M. Tilghman. 1998. Multiple mechanisms regulate imprinting of the distal chromosome 7 gene cluster. Mol. Cell. Biol. 18: 3466-3474.

Choi, O.-R.B. and J.D. Engel. 1988. Devel opmental regulation of $\beta$-globin switching. Cell 55: 17-26.

DeChiara, T.M., E.J. Robertson, and A. Efstratiadis. 1991. Parental imprinting of the mouse insulin-like growth factor II gene. Cell 64: 849-859.
Feil, R., J. Walter, N.D. Allen, and W. Reik. 1994. Developmental control of allelic methylation in the imprinted mouse I gf2 and H19 genes. Development 120: 2933-2943.

Ferguson-Smith, A.C., H. Sasaki, B.M. Cattanach, and M.A. Surani. 1993. Parental-origin-specific epigenetic modifications of the mouse $\mathrm{H} 19$ gene. Nature 362: 751-755.

Foley, K.P. and J.D. Engel. 1992. Individual stage selector element mutations lead to reciprocal changes in $\beta$ - vs. $\epsilon$-gl obin gene transcription: Genetic confirmation of promoter competition during globin gene switching. Genes \& Dev. 6: 730744.

Forne, T., J. Oswald, W. Dean, J.R. Saam, B. Bailleul, L. Dandolo, S.M. Tilghman, J. Walter, and W. Reik. 1997. Loss of maternal $\mathrm{H} 19$ gene induces changes in I gf2 methylation in both cis and trans. Proc. Natl. Acad. Sci. 94: 10243-10248.

Kay, G.F., G.D. Penny, D. Patel, A. A shworth, N. Brockdorff, and S. Rastan. 1993. Expression of Xist during mouse development suggests a role in the initiation of $X$ chromosome inactivation. Cell 72: 171-182.

Kuhn, R., K. Rajewsky, and W. Muller. 1991. Generation and analysis of interleukin-4 deficient mice. Science 254: 707713.

Leighton, P.A., R.S. Ingram, J. Eggenschwiler, A. Efstratiadis, and S.M. Tilghman. 1995a. Disruption of imprinting caused by deletion of the $\mathrm{H} 19$ gene region in mice. Nature 375: 3439.

Leighton, P.A., J.R. Saam, R.S. Ingram, C.L. Stewart, and S.M. Tilghman. 1995b. An enhancer del etion affects both $\mathrm{H} 19$ and I gf2 expression. Genes \& Dev. 9: 2079-2089.

Li, E., T.H. Bestor, and R. Jaenisch. 1992. Targeted mutation of the DNA methyltransferase gene results in embryonic le thality. Cell 69: 915-926.

Li, E., C. Beard, and R. Jaenisch. 1993. The role of DNA methylation in genomic imprinting. Nature 366: 362-365.

Marahrens, Y., B. Panning, J. Dausman, W. Strauss, and R. Jaenisch. 1997. Xist-deficient mice are defective in dosage compensation but not spermatogenesis. Genes \& Dev. 11: 156166.

M cCarrick III, J.W., J.R. Parnes, R.H. Seong, D. Solter, and B.B. Knowles. 1993. Positivenegative selection gene targeting with the diphtheria toxin A-chain gene in mouse embryonic stem cells. Transgenic Res. 2: 183-190.

Mutirangura, A., A. Jayakumar, J.S. Sutcliffe, M. Nakao, M.J. McKinney, K. Buiting, B. Horsthemke, A.L. Beaudet, A.C. Chinault, and D.H. Ledbetter. 1993. A complete Y AC contig of the Prader-Willi/Angelman chromosome region (15q11q13) and refined localization of the SNRPN gene. Genomics 18: 546-552.

Penny, G.D., G.F. Kay, S.A. Sheardown, S. Rastan, and N. Brockdroff. 1996. Requirement for Xist in X chromosome inactivation. Nature 379: 131-137.

Pfeifer, K. and S.M. Tilghman. 1994. Allele-specific gene expression in mammals: The curious case of the imprinted RN As. Genes \& Dev. 8: 1867-1874.

Pfeifer, K., P.A. Leighton, and S.M. Tilghman. 1996. The structural $\mathrm{H} 19$ gene is required for its own imprinting. Proc. Natl. Acad. Sci. 93: 13876-13883.

Ripoche, M.-A., C. Kress, F. Poirier, and L. Dandolo. 1997. Deletion of the $\mathrm{H} 19$ transcription unit reveals the existence of a putative imprinting control element. Genes \& Dev. 11: 1596-1604.

Rougeulle, C., H. Glatt, and M. Lalande. 1997. The Angelman syndrome candi date gene, U BE3A-AP, is imprinted in brain. Nature Genet. 17: 14-15.

Sasaki, H., P.A. Jones, J.R. Chaillet, A.C. Ferguson-Smith, S. Barton, W. Reik, and M.A. Surani. 1992. Parental imprinting: 
Potentially active chromatin of the repressed maternal al lele of the mouse insulin-like growth factor (I gf2) gene. Genes \& Dev. 6: 1843-1856.

Sauer, B. and N. Henderson. 1989. Cre-stimulated recombination at loxP-containing DNA sequences placed into the mammalian genome. Nucleic Acids Res. 17: 147-161.

Stoger, R., P. Kubicka, C.-G. Liu, T. Kafri, A. Razin, H. Cedar, and D.P. Barlow. 1993. M aternal-specific methylation of the imprinted mouse I gf $2 \mathrm{r}$ locus identifies the expressed locus as carrying the imprinting signal. Cell 73: 61-71.

Svensson, K., C. Walsh, R. Fundele, and R. Ohlsson. 1995. H19 is imprinted in the choroid plexus and leptomeninges of the mouse foetus. Mech. Dev. 51: 31-37.

Szabo, P.E. and J.R. Mann. 1995. Biallelic expression of imprinted genes in the mouse germ line: Implications for erasure, establishment, and mechanisms of genomic imprinting. Genes \& Dev. 9: 1857-1868.

Tremblay, K.D., J.R. Saam, R.S. Ingram, S.M. Tilghman, and M.S. Bartolomei. 1995. A paternal-specific methylation imprint marks the alleles of the mouse $\mathrm{H} 19$ gene. Nature Genet. 9: 407-413.

Tremblay, K.D., K.L. Duran, and M.S. Bartolomei. 1997. A 5' two kilobase pair region of the imprinted mouse $\mathrm{H} 19$ gene exhibits exclusive paternal methylation throughout development. Mol. Cell. Biol. 17: 4322-4329.

Tucker, K.L., C. Beard, J. Dausman, L. Jackson-Grusby, P.W. Laird, H. Lei, E. Li, and R. Jaenisch. 1996. Germ-line passage is required for establishment of methylation and expression patterns of imprinted but not of nonimprinted genes. Genes \& Dev. 10: 1008-1020.

Vu, T.H. and A.R. Hoffmann. 1997. Imprinting of Angelman syndrome gene, UBE3A, is restricted to brain. Nature Genet. 17: 12-13.

Walter, J., N. Allen, T. Kruger, S. Engemann, G. Kelsey, R. Feil, T. Forne, and W. Reik. 1996. Genomic imprinting and modifier genes in the mouse. Epigenetic mechanisms of gene regulation. pp. 195-213. Cold Spring Harbor Laboratory Press, Cold Spring Harbor, NY.

Webber, A., R.I. Ingram, J. Levorse, and S.M. Tilghman. 1998. Location of enhancers is essential for imprinting of $\mathrm{H} 19$ and I gf2. Nature 391: 711-715.

Wevrick, R., J.A. Kerns, and U. Francke. 1994. Identification of a novel paternally expressed gene in the Prader-Willi syndrome region. Hum. Mol. Genet. 3: 1877-1882.

Wu, H., X. Liu, and R. Jaenisch. 1994. Double replacement: Strategy for efficient introduction of subtle mutations into the murine Colla-1 gene by homologous recombination in embryonic stem cells. Proc. Natl. Acad. Sci. 91: 2819-2823.

Wutz, A., O.W. Smrzka, N. Schweifer, K. Schellander, E.F. Wagner, and D.P. Barlow. 1997. Imprinted expression of the Igf2r gene depends on an intronic CpG island. Nature 389: 745749.

Zemel, S., M.S. Bartolomei, and S.M. Tilghman. 1992. Physical linkage of two mammalian imprinted genes. Nature Genet. 2: 61-65. 


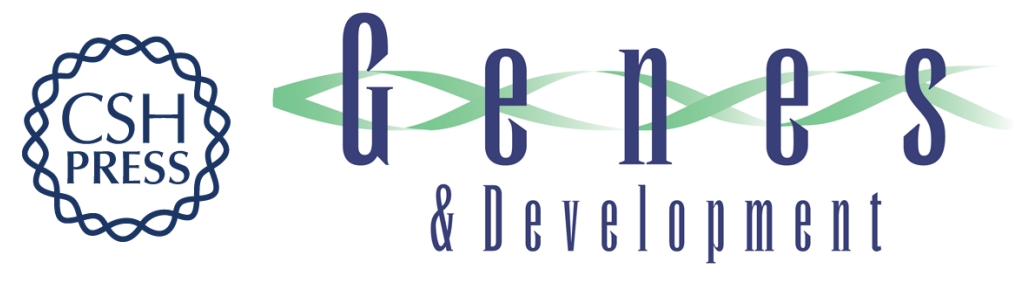

\section{Igf2 imprinting does not require its own DNA methylation or H19 RNA}

Beverly K. Jones, John M. Levorse and Shirley M. Tilghman

Genes Dev. 1998, 12:

Access the most recent version at doi:10.1101/gad.12.14.2200

References This article cites 44 articles, 21 of which can be accessed free at: http://genesdev.cshlp.org/content/12/14/2200.full.html\#ref-list-1

License

Email Alerting Receive free email alerts when new articles cite this article - sign up in the box at the top Service right corner of the article or click here.

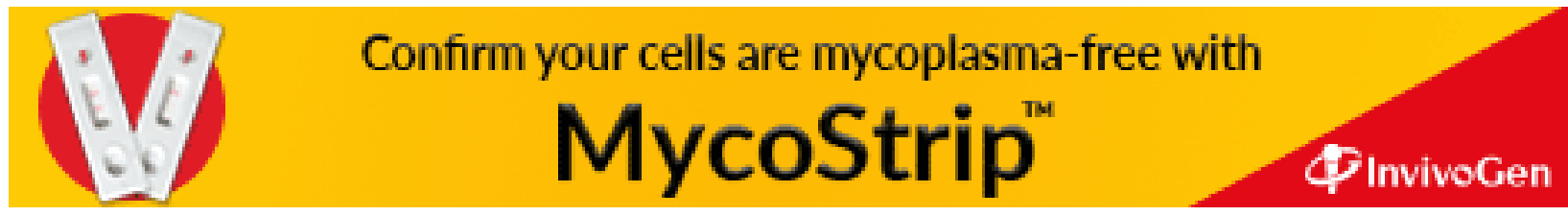

